\title{
ISLAMICJERUSALEM IN THE EYES OF SALAH AL-DIN: A CRITICAL ANALYTICAL STUDY OF THE LIBATION OF THE CITY FROM THE CRUSADERS
}

\section{Maher Y. ABU-MUNSHAR}

\begin{abstract}
Nearly a century after the brutal, and unforgiving, Crusader conquest of Islamicjerusalem, Sultan Salah al-Din succeeded in 1187CE in liberating the city. This seemingly insurmountable feat was accomplished when Salah al-Din succeeded in unifying the diverse racial, ethnic and denominational Muslims into a single, coherent fighting force under his capable leadership. Consequently, this paper explores the nature of Salah al-Din's headship and the precise strategies he used in team-building, team-management that proved essential in his bid to restore the holy city to the Muslims. Moreover, this paper will examine the striking magnanimity Salah al-Din displayed towards the Christians, and others, in Islamicjerusalem - including their holy sanctuaries.
\end{abstract}

KEYWORDS: Bayt al-Maqdis, Balian of Ibelin, Hittin, Dome of the Rock, the Holy Sepulchre, Palestine.

\section{INTRODUCTION}

Salah al-Din or Yusuf Ibn Ayyub was born in $532 \mathrm{AH} / 1137 \mathrm{CE}$ in the town of Takrit, in modern Iraq (Reston, 2001: 4). Up until that date, Islamicjerusalem was already under the rule of the Latin Kingdom of Jerusalem for nearly 38 years since 1099 CE (Maalouf, 2006:50). The family considered the birth of Salah al-Din as a bad omen, as he was born on the day in which Mujahid al-Din Bahruz -the ruler of Takrit- instructed Salah al-Din's father, uncle and the rest of the family to an immediate leave from city (Ibn Kathir, 1978,12: 272). After leaving Takrit, they went to al-Musil and offered their services to its ruler Imad al-Din Zanki. During their time in al-Musil, Salah al-Din's father, uncle and other family members were appointed to prominent government and military positions under the Zanki dynasty, whose sphere of control extended to Damascus and Aleppo. (Al-Hayik: 33-34).

At the age of 14, Salah al-Din began to learn the art of fighting, and soon stood out among the troops of Nur al-Din (Regan,1987:17) (the son and

Associate Professor of Islamic History, Humanities Department, Qatar University, Qatar, m.abumunshar@qu.edu.qa. 
successor of 'Imad al-Din Zanki), who was based in Damascus. Like his father, Nur al-Din was vying with the Crusader kingdom of Jerusalem, and both were attempting to take over Egypt. In several campaigns to Egypt between 558 and 564 AH (1163-69 CE) Salah al-Din performed impressively, outstripping his peers. He served under his uncle Shirkuh, who was commander-in-chief of the Syrian army. In the third campaign, the two men led the Syrian forces to Egypt at the request of Shawar, the powerful wazir (minister) of the Fatimid Caliph al-'Adid in Cairo, to help Egypt resist the Crusaders. When Shawar was killed, al-'Adid appointed Shirkuh as wazir of Egypt - effectively its ruler, as under the weak Fatimids power was in the hands of the wazir. Two months later Shirkuh died unexpectedly and was succeeded by Salah al-Din. It was still $564 \mathrm{AH} / 1169 \mathrm{CE}$, (a significant year for the 32-year-old commander (Richards, 2001:41-45).

Salah al-Din had little regard for al-'Adid, and on the caliph's death in 567 $\mathrm{AH} / 1171 \mathrm{CE}$ he immediately seized power, not as caliph, but in the name of Nur alDin, who recognised the Abbasid caliphate in Baghdad. Salah al-Din began to reform Egypt and to turn it into a powerhouse, restoring the Sunni school of figh and becoming the country's unquestioned ruler (Ibn Shaddad, 2000: 26-28). After Nur al-Din's sudden death in $569 \mathrm{AH} / 1174 \mathrm{CE}$, leaving a 12-year-old son, alMalik al-Salih Isma'il, Salah al-Din asserted his right to the succession on grounds that al-Salih would not be able to shoulder the burden of kingship or defend the lands against the Crusaders. It was also apparent that the unity Nur al-Din had achieved between the various emirates in al-Sham was in danger of fragmenting (Ibn Shaddad, 2000: 31).

The following year Salah al-Din proclaimed himself sultan (ruler) of Egypt and al-Sham - those parts of it that he now held. Two months later the Abbasid caliph in Baghdad, al-Mustadi' Bi'amrillah (d. $576 \mathrm{AH} / 1180 \mathrm{CE}$ ) formally confirmed Salah al-Din as sultan of the combined governments of Egypt, Yemen and alSham. The caliph told him not to covet al-Salih's fiefdom of Aleppo and to maintain good relations with the youth. (Regan, 1987:36) However, al-Salih died in $577 \mathrm{AH} / 1181 \mathrm{CE}$.

\section{ISLAMICJERUSALEM IN THE EYES OF SALAH AL-DIN}

Islamicjerusalem occupied a very distinctive position in the mind of Salah al-Din (Glubb, 1999, 2(2): 49-69). There is no doubt that he saw the liberation of the city as a top priority, and between his appointment as wazir and his eventual departure to recover Islamicjerusalem from the Crusaders he spent time consolidating the Muslim armies and uniting Muslim territory, as well as reminding Muslims of the importance of this holy region. In a speech to his fellow Muslims, reported by 'Imad al-Din al-Asfahani (n.d: 39) Salah al-Din said:

If God blesses us by enabling us to drive His enemies out of Jerusalem, how fortunate and happy we are going to be! For the enemy has controlled Jerusalem for ninety-one years, during which time God did not accept any deeds from us. At the same time, the zeal of the Muslim rulers to deliver it 
faded away. Time passed, and so did many generations, while the crusaders succeeded in rooting themselves strongly there...

Thus, recovering Islamicjerusalem was Salah al-Din's ultimate target. His biographer, Baha' al-Din Ibn Shaddad (2000: 26) heard Salah al-Din say: "When God enabled me to gain Egypt, I realised that he willed the conquest of the coast (Syrian coast), because he had put the idea in my mind". It seems that Salah alDin considered the recovery of Islamicjerusalem and the Syrian coast, as well as his rule over Egypt, to be a divine command that he was obliged to fulfil. These two objectives were not new; they were the common ambition of all Muslims, and he had grown up with them. But given his position, Salah al-Din felt more responsible than other Muslims for achieving these goals because he had the power to do so.

After the death of Nur al-Din in Damascus in 569 AH / May 1174 CE, leaving a 12-year-old son with no institutional procedure for succession, the political situation was very dangerous; the Sultanate could not be governed by a young child. A struggle for succession between its most powerful commanders threatened the stability of the region and plunged al-Sham into a civil war that destroyed all that Nur al-Din had achieved. Salah al-Din received many invitations from commanders, religious leaders and Muslim thinkers asking him to come to al-Sham to resolve the situation. 'Imad al-Din al-Asfahani wrote informing him of the situation in al-Sham, the danger that this posed to the Muslim nation, and urging him to intervene to prevent the country being fragmented by power struggles (Dajani - Shikail, 1993: 180-3). Five months after the death of Nur al-Din, Salah al-Din set off for al-Sham. According to Ibn Shaddad (2000: 49-51)::

\begin{abstract}
When Salah al-Din received confirmation of Nur al-Din's death, and as he was aware that his son was a child unable to shoulder the burdens of kingship and incapable of taking on the defence of the lands against God's enemies, he made his preparation to march to Syria, since it was the cornerstone of Muslim territory ... Salah al-Din arrived in Syria demanding that he himself should take on al-Salih's guardianship, direct his affairs and set straight what had gone awry. Salah al-Din reached Damascus, without having renounced allegiance, and entered the city after a peaceful handover on Tuesday, the last day of Rabi' al-Thani $570 \mathrm{AH}$ (27 November $1174 \mathrm{CE}$ ), and he took over the citadel.
\end{abstract}

It seems that Salah al-Din was certain that what he did was an essential step towards recovering Islamicjerusalem. He realised that uniting Muslim ranks and saving Nur al-Din's kingdom would allow the Crusaders further south to be effectively resisted, and would ensure that he would not be attacked from the rear.

The profound significance of Islamicjerusalem to Salah al-Din was shown after he conquered the city, in the care he took over the sermon to be preached in the al-Aqsa mosque on the first Friday after the city's liberation. He invited the 
greatest Muslim preachers to submit draft sermons to him. His final decision was determined by the strength and intensity of the ideas he wanted conveyed to Muslims about the significance of the holy city (Al-Hanbali, 1999, 1:477-83).

\section{THE ROAD TO ISLAMICJERUSALEM}

As the Muslim army marched south from Damascus they won a number of victories over the Crusaders, but the most important and decisive battle was that of Hittin (known in western literature as Hattin, or the Horns of Hattin), on 24 Rabi' al-Thani 583 AH /4 July 1187 CE near the Sea of Galilee (Abu Shama, 1997,3 :275-88). Here the Muslim forces heavily defeated a combined Christian army, killing or capturing a huge number of them. Among those taken were Guy of Lusignan, king of the Latin kingdom of Jerusalem; his counsellors; his brother Amaury, the constable of the kingdom; the grand masters of the Knights Templar and the Hospitallers (the Knights of the Order of the Hospital of St John of Jerusalem); and many knights from these two military-religious orders. The only surviving leaders, who fled to safety through Muslim lines, were Raymond of Tripoli, Reynald of Sidon and Balian of Ibelin (referred to in Arabic sources as Balian Ibn Barzan). These men had enjoyed friendly relations with Salah al-Din and were suspected by the Crusaders of complicity with him (Morgan, 1973:4144). The common soldiers taken at Hittin were sold in the slave market at Damascus.

Salah al-Din camped on the field of battle and ordered the leaders of the captured soldiers be brought before him. This encounter received wide coverage from Muslim historians, such as Ibn Shaddad (2000: 51), 'Imad al-Din (n.d:19-20) Abu Shama (1997:288-89), Ibn al-‘Adim (1996:408-09), Abu al-Fida' (1997, 2:155), al-Hanbali (1999, 1, 464-65 and from non-Muslim historians like Runciman (1952, 2:459-60) who wrote:

There Saladin received King Guy and his brother the Constable Amalric, Reynald of Chatillon and his stepson Humphrey of Toron, the Grand Master of the Temple, the aged Marquis of Montferrat, the lords of Jebail and Botrun, and many of the lesser barons of the realm. He greeted them graciously. He seated the King next to him and, seeing his thirst, handed him a goblet of rose water, iced with the snows of Hermon. Guy drank from it and handed it on to Reynald who was at his side. By the laws of Arab hospitality to give food or drink to a captive meant that his life was safe; so, Saladin said quickly to the interpreter: 'Tell the King that he gave the man drink, not I.' He then turned on Reynald whose impious brigandage he could not forgive and reminded him of his crimes, of his treachery, his blasphemy and his greed. When Reynald answered truculently, Saladin himself took a sword and struck off his head. Guy trembled, thinking that his turn would come next. But Saladin reassured him. 'A king does not kill a king,' he said, 'but that man's perfidy and insolence went too far.' He then gave orders that none of the lay barons was to be harmed but that all were to be treated with courtesy and respect during their 
captivity. But he would not spare the knights of the military orders, save only the Grand Master of the Temple...

This established the pattern for Salah al-Din's treatment of the Crusaders - both in his magnanimity towards King Guy and his harshness toward Reynald. Ibn Shaddad justified the latter, saying that Salah al-Din had vowed to kill Prince Reynald if he had him in his power. The reason was that a caravan from Egypt had passed through Reynald's territory at Shawbak during a time of truce. They had halted there under conditions of safe conduct, but Reynald had killed them. Salah al-Din heard of this and swore in the name of God that if he captured Reynald he would kill him (Al-Dhahabi, 1999, 2:96).

Salah al-Din's goal was to move towards Islamicjerusalem. To open the way, he first had to conquer the cities in the region. The Crusader losses at the battle of Hittin had added to their serious manpower shortage. Within a period of two months, from July to September that year, Salah al-Din had recovered all the inland cities and fortresses such as al-Karak, al-Shawbak, Nablus and Nazareth except the walled city of Islamicjerusalem. He also conquered all major ports between 'Asqalan (Ashkelon) and Jubayl except for Sur (Tyre). (Ibn AlAthir, 1998, 10: 145-54) As a result, the land route between Palestine and Egypt was cleared for the movement of the Muslim army. Salah al-Din then established his fleet in the Mediterranean between Alexandria and Acre. His ships went into action on Jumada al-Thani, $583 \mathrm{AH} /$ September $1187 \mathrm{CE}$ and blocked the movement of Crusader ships in the area under its control. It was essential for Salah al-Din to deny easy bridgeheads to potential Crusader support forces from Europe, and he spent the ensuing weeks capturing as many coastal towns from the Crusaders as possible.

Having gained 'Asqalan on 16 Jumada al-Thani, 583 AH /5 September 1187 CE and arranged for its administration, Salah al-Din summoned all his troops, who were scattered along the coast. He then marched on Islamicjerusalem (Ibn Shaddad, 2000: 52-53). On reaching the walled city, the sultan enquired about the location of the al-Aqsa mosque and the shortest route to it (Abu Shama, 1997, 3: 336), which he described as "the shortest route to Heaven". (AlAsfahani, n.d: 40). As "Imad al-Din reports, he swore to restore the sacred shrines to their old grandeur and vowed not to leave Islamicjerusalem until he had recovered the 'rock on which the Prophet had set foot,' had visited it personally and raised his flag on its highest point. (Al-Asfahani, n.d: 40).

According to Muslim chronicles, Salah al-Din and his army approached Islamicjerusalem from 'Asqalan on the western side of the walled city on Sunday 15 Rajab 583AH /20 September 1187 CE (Ibn Shaddad, 2000: 53). Lane-Poole (1985:226) says that Salah al-Din stationed his forces opposite the western wall between Jaffa's Gate (Bab al-Khalil) and Damascus Gate (Bab al-'Amud), and began to besiege the city. Muslim historians do not give the exact location of the Muslim army in these first few days of the siege. 
The Crusaders were worn down by two weeks of unremitting assault, with arrows raining down on them. On 21 Rajab/26 September Salah al-Din ordered his camp to be quietly moved. When the people of Jerusalem saw this they relaxed, but Salah al-Din had only spread out his camp across the nearby hills. He then ordered assault engines (mangonels) to be built, and formed a group of 10,000 cavalry and 10,000 archers (Runciman (1952, 2:464).

On Friday 20 Rajab/25 September, Salah al-Din set up his mangonels and commenced his final attack on the city. Ibn Shaddad (2000: 53) gives a brief account of the battle, stating that Salah al-Din pressed his attack until a hole was made in the wall overlooking the valley of Hinnom (Wadi Jahannam). Realising the inevitability of their defeat, the besieged Crusaders conferred and agreed to surrender Jerusalem to Salah al-Din and to seek safe conduct for themselves. They sent messengers asking the Muslim leader for a settlement, and an agreement was reached soon after.

Ibn al-Athir's (1998, 10: 155) account of the battle is more detailed. According to him, on the night of 20 Rajab/25 September Salah al-Din installed his mangonels and by morning these machines were in operation. The Crusaders set up their own mangonels on the wall and began firing catapults. Both sides fought bravely, each considering the struggle to be in defence of its faith. The Crusader cavalry emerged from the city daily to engage in combat with Salah alDin's forces, and both sustained casualties. In one of these battles, Ibn al-Athir says that the Crusaders killed 'Izz al-Din Isa Ibn Malik, a Muslim commander. His death so grieved the Muslims that they violently charged the Crusaders, forcing them from their positions and pushing them back to the city wall. The Muslims then crossed the moat and reached the wall. Their sappers prepared to destroy it, while archers gave cover and mangonels continued their bombardment.

Ibn al-Athir (1998, 10: 155-56) agrees with Ibn Shaddad that the Crusader leaders, realising that they were on the verge of perishing, met in council and agreed to surrender Jerusalem to Salah al-Din and ask him for safe conduct. But Salah al-Din turned their delegation away, saying he would deal with them in the same way they had dealt with the city's inhabitants in $492 \mathrm{AH} / 1099 \mathrm{CE}$ - by killing and the taking of prisoners. However, different chroniclers give four different accounts of the communications between Salah al-Din and Jerusalem's rulers about surrender.

\section{ACCOUNTS OF NEGOTIATIONS}

According to Runciman (1952, 2: 464), on 2 October Balian of Ibelin (Balian Ibn Barzan) left Jerusalem to discuss the future of the city and its people with Salah al-Din. This was not, it seems, the first attempt at communication but had been preceded by four others. The first of these was reported by Abu Shama (1997,3: 329) who quoted Ibn al-Qadisi's story that Salah al-Din, in a letter to his relatives, had said that the king of Jerusalem had contacted him during his attack on Tyre, 
in $583 \mathrm{AH} / 1187 \mathrm{CE}$, to ask for safe conduct (aman) and that Salah al-Din had responded, 'I will come to you in [Islamic] Jerusalem'. Ibn al-Qadisi adds that the astrologers had informed Salah al-Din that the stars indicated he would enter Islamicjerusalem but would lose one eye. To which Salah al-Din replied, 'I would accept becoming blind if I took the city' (Abu Shama, 1997, 3: 329). At that time only the siege of Tyre prevented the sultan from going to Islamicjerusalem.

The second attempt at negotiation was reported by Lane-Poole (1985, 223-25), who quoted Ernoul, the Crusader chronicler who was in Jerusalem during Salah al-Din's siege. Ernoul provided details that did not appear in Arabic sources. He indicated that on the day the Muslims took 'Asqalan, a delegation from Jerusalem went to ask Salah al-Din for a peaceful solution for their city. On the day of the meeting, there was a solar eclipse, which the Crusader delegates considered a bad omen. Salah al-Din was keen to spare the holy city the misery of a siege, because 'Jerusalem is the house of God, as you also believe, and I will not willingly lay siege to the house of God or put it to the assault'. He offered them generous terms: they would be allowed to remain in the city temporarily; they could retain the surrounding land within a radius of five leagues, and they would receive the supplies of money and food they needed until the following Pentecost. If the inhabitants of Jerusalem had any prospect of being rescued by an external force, they should keep the holy city, but if not, they were to surrender it and Salah al-Din would conduct them and their possessions safely to Christian lands. The delegation refused this offer without hesitation, saying: "if God pleases, [we] would never surrender the city where the Saviour died for [us]". Salah al-Din then vowed that he would never take Islamicjerusalem except by force, and commenced his march against the city.

The third attempt was reported by 'Imad al-Din Al-Asfahani (n.d: 35) who says that when Salah al-Din was at Tyre, he brought the captured king of Jerusalem - Guy of Lusignon - and the grand master of the Templars before him and promised them freedom if they would help him secure the surrender of other cities. In fact, they did help him later to obtain the surrender of 'Asqalan and Gaza.

The fourth account is reported by Runciman (1952, 2: 463). He says that Balian of Ibelin, who was with the Frankish (Crusader) refugees at Tyre, contacted Salah al-Din and asked for a safe conduct to enter the city of Jerusalem in order to rescue his wife Queen Maria (he had married the widow of Amalric, king of Jerusalem), who had retreated there from Nablus with her children, and whom he wished to bring to Tyre. Salah al-Din granted this request on condition that Balian spends only one night in the city and did not carry arms. By acceding to Balian's request, it seems that Salah al-Din hoped to use him as his chief negotiator in Jerusalem's surrender. Balian ultimately did negotiate the surrender of the city, but only after, he had broken his agreement with Salah alDin and had played a dramatic role in the city's defence (Runciman, 1952, 2: 464). 
When Balian arrived in Islamicjerusalem, Patriarch Heraclius and the officers of the military orders insisted that he should stay and lead the city's defence. At first Balian refused, saying that he would keep his commitment to Salah al-Din. However, at the insistence of the patriarch, Balian, deeply embarrassed, wrote to Salah al-Din to explain the violation of his oath. Runciman (1952, 2: 463) says that Salah al-Din was always courteous to an enemy whom he respected. He not only forgave Balian but sent an escort to convey Queen Maria and her family to Tyre. Salah al-Din is said to have wept when he saw these children, heirs to vanished grandeur, passing through his camp into exile. Balian finally consented to accept the leadership of the city and immediately began to consolidate the Crusader forces and plan the defence (Runciman, 1952, 2: 463).

\title{
BALIAN'S THREAT TO DESTROY THE CITY
}

It seems that Balian came to the conclusion that the massacre committed by the Crusaders against the Muslims when they first entered Islamicjerusalem would sooner or later be repeated against them, and that all the Christians (both the Crusaders and indigenous Christians) in the city would be killed or captured. Most probably, they would be killed. Balian concluded that the only solution was to threaten Salah al-Din. Ibn Al-Athir (1998, 10:156), Abu Shama (1997, 3: 340), Abu al-Fida' (1977, 2: 156-57), Ibn Kahir (1978, 12: 323), Ibn al-'Ibri (1992, 221), AlHanbali (1999, 1: 473) and other Muslim and non-Muslim chroniclers are unanimous about the content of Balian's speech to Salah al-Din:

\begin{abstract}
O Sultan, he said, know that we soldiers in this city are in the midst of God knows how many people, who are slackening the fight in the hope of thy grace, believing that thou wilt grant it then as thou hast granted it to the other cities- for they abhor death and desire life. But for ourselves, when we see that death must needs be, by God we will slaughter our sons and our women, we will burn our wealth and our possessions, and leave you neither sequin nor smallest amount to loot, nor a man or a woman to enslave; and when we have finished that, we will demolish the Rock and the al-Aqsa Mosque, and the other holy places, we will slay the Muslim slaves who are in our hands - there are 5000 such, and slaughter every beast and mount we have; and then we will go out in a body to you, and will fight you for our lives: not a man of us will fall before he has slain his like; thus shall we die gloriously or conquer like gentlemen.
\end{abstract}

It can be seen from this that if Salah al-Din would not grant the people of Jerusalem fair terms of surrender, Balian would order them to fight to the death and to destroy much of the city. Balian and his soldiers were therefore prepared to violate the sacredness of Muslim holy places by destroying the Dome of the Rock and massacring Muslim prisoners of war, who were estimated to number in the thousands. There is no doubt about the dramatic impact of this message.

Regan (1987: 150-51) comments that Salah al-Din was forced to reconsider. The sultan had sworn to take the city by force and to repay the Crusaders for 
their massacre. However, becoming master of a ruined city, with its holy sites destroyed, would have been a tragic end to the holy war. Regan questions whether a voluntary surrender by the defenders would have violated Salah alDin's oath. He adds that the siege had already been bloody enough. He suggests that it was generous terms, rather than military might, that had facilitated the surrender of other cities. Moreover, conquering Islamicjerusalem by force would take longer and would affect the capabilities of Salah al-Din's forces. He concludes that Salah al-Din understood that generosity was his most potent weapon (Regan 1987: 151).

Salah al-Din discussed the situation with his commanders, and was at first told that the right approach was to cause humiliation by taking the enemy and their families as prisoners of war. However, after lengthy negotiation with Balian, terms of surrender were finally agreed (Ibn Al-Athir, 1998, 10: 156). The city was to surrender unconditionally, but the Crusaders were granted safe conduct to leave, provided that they paid a ransom fixed at ten dinars for a man, five for a woman, and two for a child (Ibn Shaddad, 2000, 53). Seven thousands of the poor would be freed for a lump sum of 30,000 dinars (Ibn Al-Athir, 1998, 10:156).

Salah al-Din saw this as an excellent opportunity to capture Islamicjerusalem without further bloodshed. All those who paid their ransom within 40 days were allowed to leave, while those who could not pay it would be enslaved. The Crusaders were allowed to take with them any movable property. However, they were encouraged to sell as much as possible to the Muslims, either to merchants in Salah al-Din's army or to local Christians (Ibn Al-Athir, 1998, 10:158), in order to raise their ransom. 'Imad al-Din reports that Balian promised to pay 30,000 dinars to free the poor. He says the offer was accepted, and that Balian fulfilled this promise (Ibn al-'Adim, 1996:411-12).

\section{THE SURRENDER OF ISLAMICJERUSALEM}

The walled city of Islamicjerusalem surrendered on Friday 27 Rajab 583 AH/2 October 1187 CE, and according to 'Imad al-Din al-Asfahani (n.d: 43), it contained more than one hundred thousand people, including Christian men, women and children. Salah al-Din entered the city and freed it from 88 years of Crusader rule. The 27 Rajab was the same date on which the Prophet Muhammad had been supernaturally transported from Makkah to Islamicjerusalem in a single night, known as the Ascent, on the eve of al-Mi'raj, as recorded in the Qur'an (al-Isra', v. 1). Ibn Shaddad (2000:52-54) says that God facilitated this remarkable coincidence of restoring Islamicjerusalem to Muslim hands on the anniversary of the Night Journey and the Ascent of the Prophet Muhammad. He adds that a large number of people from all over the Muslim world had come to the region after hearing about the conquest of the coastal lands, hoping for the capture of Islamicjerusalem. Many notables from Egypt and Syria witnessed the liberation, so that when Salah al-Din entered the city he was surrounded by scholars, jurists, 
Sufis and poets, as well as by a crowd of civilians and military officers. On the day of the conquest the huge cross that had been placed over the Dome of the Rock was pulled down and Salah al-Din released all Muslim prisoners, who, according to Ibn Shaddad, numbered close to three thousand (Ibn Shaddad, 2000:52-54).

The Patriarch Heraclius and his priests each paid their ten dinars and left the city laden with gold and silver jewellery, relics by the cartload and other artifacts from the church of the Holy Sepulchre. According to 'Imad al-Din AlAsfahani (n.d: 47), the Crusaders stripped the ornaments from their churches, carrying with them vases of gold and silver, silk- and gold-embroidered curtains and other church treasures.

Salah al-Din's brother, al-Malik al-‘Adil, was so moved by this scene that he asked for a thousand captives. Salah al-Din granted his request, and al-'Adil immediately set them free. Salah al-Din himself set free all the aged prisoners (Runciman, 1952, 2:466). An example of his magnanimity is that he sent his guard to proclaim throughout the streets of Jerusalem that all old people who could not pay the ransom would be allowed to leave the city. Lane-Poole says that they came forth from the Postern of S. Lazar, and their departure lasted from the rising of the sun until night fell (Lane-Poole, 1985:232).

'Imad al-Din Al-Asfahani (n.d: 43), Ibn Al-Athir (1998, 10:157), Abu Shama (1997, 3: 343) were among historians who reported the gracious conduct of Salah al-Din towards many noble women of the city, allowing them to leave without ransom. For example, a Byzantine queen, who had led a monastic life in Jerusalem, was not only allowed to leave without ransom, but was permitted to take all her belongings and whatever else she wanted. Another example was the wife of the captured King Guy, who was allowed to leave the city unhindered, with her retinue and associates. Salah al-Din even granted her safe conduct to visit her captive husband in Nablus 'Imad al-Din Al-Asfahani (n.d: 43). Some of Salah al-Din's commanders (for example, the ruler of al-Bira) asked for the freedom of 500 Armenians, as they were from his country. Muzaffar al-Din Ibn 'Ali Kuchuk requested the release of 1,000 captives, claiming that they had come from his home town of al-Ruha (Urfa). Salah al-Din granted his request (Lyons \& Jackson, 1982: 257).

Runciman (1952, 2:466) reports that some of the Crusader ladies who ransomed themselves came to Salah al-Din in tears and asked what was to happen to them, as their husbands or fathers had been slain or taken captive. He replied by promising to free those of their husbands who were in captivity, and to the widows and orphans of men who had been slain he gave money and gifts from his own treasury according to their need. Runciman commented that this incident was in contrast to the deeds of the conquerors of the First Crusade.

In order to control the departing population Salah al-Din ordered that all the gates of walled city be temporarily closed. At each gate, a commander was 
appointed to monitor the movements of the Crusaders and to ensure that only those who had paid a ransom could leave. Others were employed inside the city to take a census (Al-Hanbali, 1999, 1:473). 'Imad al-Din Al-Asfahani (n.d: 44) says that Egyptian and Syrian officers were appointed to collect the payments and to give the departing people receipts that had to be submitted at the gates. The grand masters of the Templars and Hospitallers were approached to donate money for the release of poor Crusaders. When they resisted, a riot almost erupted and they were forced to contribute to the ransoms (Runciman, 1952, 2: 466).

As the Crusaders were leaving, Salah al-Din assigned officers whose job was to ensure their safe arrival in territories held by the Christians (Ibn Shaddad, 2000: 53). Regan (1987:153) quotes an unnamed chronicler who gave Salah alDin's officers credit for their humane treatment of the refugees:

[The officers] who could not endure the suffering of the refugees, ordered their squires to dismount and set aged Christians upon their steeds. Some of them even carried Christian children in their arms.

After the exodus, the 15,000 people who remained in the city were enslaved, as they could not pay the ransom. According to 'Imad al- Din Al-Asfahani (n.d: 47), 7,000 were men and 8,000 were women and children. 'Imad al- Din was amazed at the amount of treasure that was carried away by the Crusaders. He reported to Salah al-Din that it could be valued at 200,000 dinars. He reminded the sultan that his agreement was for safe conduct to the departing Crusaders for themselves and their personal property, but not for the property of the churches, and he advised that such treasures should not be left in their hands, but Salah al-Din replied:

If we interpret the treaty [now] against their interest, they will accuse us of treachery. Let us deal with them according to the wording of the treaty so they may not accuse the believers of breaking the covenant. Instead, they will talk of the favours that we have bestowed upon them.

Salah al-Din's magnanimity contrasts sharply with the attitude of the victorious Crusaders in 492AH /1099 CE. He was chivalrous and fair-minded to his enemies, and his generosity was recognised by Muslim and Christians alike.

Hillenbrand (2012: 316) says that the propaganda value of Salah al-Din's bloodless conquest of Jerusalem counts for much more than the temptations, soon overcome, to exact vengeance. She adds that it was important for Muslim chroniclers like Ibn al-Athir to display the magnanimity of Salah al-Din's conduct not just as a personal characteristic, but also as a demonstration of the superiority of Muslim conduct over Christian conduct, and of Islamic values over Christian values. Salah al-Din was steeped in Islamic teaching, and his treatment of the Christians reflected the original Muslim vision for the treatment of nonMuslims that was established in the Qur'anic verse (al-Mumtahana, v. 8): 
God forbids you not, with regard to those who fight you not for [your] Faith nor drive you out of your homes, from dealing kindly and justly with them: for God loves those who are just.

The instructions of Islam restrained him from barbaric acts, and it is likely that the concept of 'forgiveness with capability' (al-'Afu 'ind al-Maqdirah) was in his mind at the time.

\title{
SALAH AL-DIN AND THE HOLY PLACES
}

The first action that Salah al-Din took towards the church of the Holy Sepulchre, the holiest place in the world for Christians, was to ordered it to be closed for three days (Abu Shama, 1997, 3:402). This allowed the situation to calm down and life to return to a semblance of normality (Al-'Arif: 176). The closure was also gave the sultan and his advisers time to discuss the church's future after a long and tiring war. Some of his advisers wanted him to destroy the church and put an end to Christian interest in Islamicjerusalem, so that they would no longer come for visits and pilgrimages. 'Imad al-Din Al-Asfahani (n.d: 53-54) says that:

\begin{abstract}
Salah al-Din discussed with his people the issue of the church of the Holy Sepulchre. Amongst them were those who advised that its structures should be demolished, its traces should be blotted out, the way to visiting it should be blinded, its status should be removed, its candelabras should be extinguished, its gospels should be destroyed, its seductions should be removed and its pronouncements should be exposed as lies...
\end{abstract}

However, most of the advisers rejected this, arguing that it was the site and not the building that mattered; Christians would still make pilgrimage because of the sanctity of the place. They also reminded the sultan that when Caliph 'Umar Ibn al-Khattab conquered the city he did not destroy the holy places, but had confirmed the right of Christians to them (Abu Shama, 1997, 3:402). Why should the conquering Muslims now destroy the Holy Sepulchre? Salah al-Din was persuaded by this majority opinion and 'Umar's example. After three days of closure he ordered the church reopened and granted Christians freedom of worship in it. However, Crusader pilgrims would be admitted only on payment of a fee (Al-Maqrizi, 1997, 1:210-11).

Salah al-Din introduced some structural changes in the course of restoring the Muslim holy places. As mentioned, the golden cross that had dominated the Dome of the Rock was taken down (Ibn Shaddad, 2000: 53). The al-Aqsa mosque was cleared of Christian furnishings and fitted with beautiful oriental carpets. Its walls were illuminated with texts from the Qur'an and rich candelabra were hung from the ceiling (Abu Shama, 1997, 3: 377). Salah al-Din also installed a minbar (carved pulpit) in the mosque. According to Abu Shama (1997, 3:392-3), this minbar had been prepared by Nur al-Din, to accompany him to Islamicjerusalem should the city be liberated during his lifetime. 
After discussion with Muslim scholars ('ulama), Salah al-Din established new religious institutions in buildings previously used by Christians. It was argued that these Christian places had been Muslim prior to the Crusades. For example, al-madrasa al-salahiyya, a school for teaching shafi'i figh, was set up in the church of St Anne. Al-khanqah al-salahiyya, a monastery (ribat) for Sufis, was placed in the former residence of the patriarch of Jerusalem, adjacent to the church of the Holy Sepulchre (Al-Hanbali, 1999, 1:485). A hospital, al-bimaristan al-salahi, was established in a church in the Tanners quarter (hayy al-dabbagha) near the Holy Sepulchre. Rich endowment was arranged to service the hospital, which apparently also functioned as a medical teaching centre (Al-Asfahai, n.d: 318).

\section{SALAH AL-DIN AND THE LOCAL CHRISTIANS}

In his treatment of the Christians in Islamicjerusalem, Salah al-Din made a distinction between two groups. On the one hand were the Crusaders, invaders who had instigated a horrific massacre after their conquest of the city, and on the other hand were the indigenous Christians, who were both Arab and nonArab followers of the Greek Orthodox Church - eastern Orthodox Christians as opposed to the Latin (Roman Catholic) Crusaders.

According to 'Imad al-Din Al-Asfahani (n.d:47-48) and Abu Shama (1997,3:158), the local Christians now requested permission to remain in the city, which Salah al-Din granted with conditions: after paying their ransom they should pay the jizyah tax, agree to be his subjects and accept the role of dhimmis. However, the poorer classes, who did not have money, were exempted from the jizyah. At the same time, Salah al-Din ordered the Crusader Christians to leave Islamicjerusalem. The Orthodox Christians and the Jacobites (Syrian Orthodox) were allowed to remain and to worship as they chose. 'Imad al-Din says that Salah al-Din even allowed them to work in his service and in the government, although he gives no examples. Arnold agrees with Imad al-Din AlAsfahani (n.d: 48) that the local Christians were satisfied with their Muslim employers (Arnold, 1986: 91).

Salah al-Din's attitude to the local Christians seems to have been partly due to the warm relations he enjoyed with the Byzantine emperor, Isaac Angelus. Runciman reports that Salah al-Din received a message from the emperor just after the liberation of Islamicjerusalem, congratulating him on his victory over the Crusaders and requesting that he convert the churches in the city back to the Orthodox Church, and that all Christian ceremonies in the city be conducted according to the Greek Orthodox liturgy. His request was later granted, although the rights of other sects were protected (Runciman, 1952, 2: 467-8). Salah al-Din allowed the local Christians to pray freely in their churches, and handed over control of Christian affairs to the Byzantine patriarch. Regan suggests that Salah al-Din saw this as a good opportunity to foster the disagreements between the followers of the Roman and Orthodox Churches 
(Regan, 1987:155) in a divide and rule strategy. There is no doubt that the Orthodox Christians and their priests benefited greatly from the departure of the Catholics from Jerusalem, as they were able to recover sovereignty over the Christian holy places ('Ashur, 1986, 2: 649).

During the siege of the city, the attitude of the indigenous Christians towards Salah al-Din was one of collaboration. Some argue that Salah al-Din would not have been able to conquer the city without their help. They maintained secret contact with Salah al-Din though Yusuf Batit ('Ashur, 1986, 2: 645), an Arab Orthodox scholar from the city. They were ready to help the sultan and his army liberate Jerusalem by opening the gates at an agreed time. It is undeniable that there was some sort of collaboration between the two sides.

Regan (1987:142) argues that one reason behind the requests of Balian and the patriarch proposing the city's surrender and asking for safe conduct is that they doubted the loyalty of the local Christians. It was well known to the Crusaders that thousands of Greek Orthodox Christians in Jerusalem would welcome a Muslim conquest to liberate them from the domination of the Church of Rome. At the beginning of the Crusades, these local Christians were excluded from living in the city. Later, during the time of Baldwin I (king of the Latin kingdom of Jerusalem 1100-18 CE), the Crusaders allowed considerable numbers of them to return, mainly to populate the city and ensure that there were enough people to carry out the necessary business of the realm. According to Runciman (1952, 2: 464-5) these local Orthodox Christians were made to attend ceremonies in which the language and rituals were alien to them. He adds that they were the majority and resented the domination of the Catholic Crusaders, and looked back with nostalgia to the days under Muslim rulers such as Caliph 'Umar, when they could worship freely Runciman (1952, 2: 464-5). Arnold 1986: 96) confirms their greater religious security under the Muslims:
The Native Christian certainly preferred the rule of the Muhammadans [Muslims] to that of the Crusaders, and when Jerusalem fell finally and ever into the hands of the Muslims (A.D. 1244), the Christian population of Palestine seems to have welcomed the new masters and to have submitted quietly and contentedly to their rule.

However, it seems that Salah al-Din's recovery of Islamicjerusalem took place without physical intervention of the Orthodox Christians.

In contrast to the religious exclusivism of the Crusaders, Salah al-Din made Islamicjerusalem an open place to all Christian denominations and sects and allowed them to practice their rituals as they wished. He returned to the Coptic priesthood all former Coptic churches, monasteries and other property taken by the Crusaders. It was reported that he also granted the Copts a place in Islamicjerusalem known as dayr al-Sultan (monastery of the sultan). Ever since the establishment of the Latin kingdom of Jerusalem - almost ninety years Egyptian Orthodox Copts had been banned from the holy city because they 
were regarded by the Latins as heretics and atheists (Ibn Al-Muqaffa', 1959, 2(2): 249) .However, Salah al-Din allowed them to visit the church of the Holy Sepulchre and other Christian sites. He also exempted them from paying fees to enter Islamicjerusalem, largely on the basis that they were his subjects (Meinardus, 2002: 137).

Interestingly, Salah al-Din also treated the Christians of Habsha (Abyssinia) generously, particularly in exempting them from fees when they visited the holy places ('Ashur, 1968, $14: 22$ ), 'Ashur (1968, $14: 22$ ) adds that Salah al-Din showed respect to their monasteries and kindness to the Habashi priest who took care of these places. It is evident that Salah al-Din succeeded in allowing different religions and sects to co-exist in Islamicjerusalem, and did not impose new practices or regulations when he conquered the city. For him, the principles contained in 'Umar's Assurance of Safety were the most appropriate guide, as the above examples show.

\section{CONCLUSION}

In this paper, I have demonstrated that for Salah al-Din liberating Islamicjerusalem was the ultimate goal for whose realisation he tirelessly worked during his life. He spared no means for its liberation from the Crusaders despite all the political and military difficulties he encountered. Salah al-Din's deep belief in the religious and political importance of Islamicjerusalem and the need to restore it to the Muslim rule were the reasons that motivated him to liberate Islamicjerusalem. I have also shown that Salah al-Din proved himself as a model leader with magnanimity, compassion and tolerance. Salah al-Din sought to negotiate with the Crusaders for a peaceful end to the siege of the walled city of Islamicjerusalem, for he wanted to preserve the lives and the souls of the Crusaders in the walled city and guarantee a safe passage for the Crusaders who were leaving the city to reach the destinations they preferred. These exemplary behaviours won him accolades from many western historians; he was described with qualities such as dignity, generosity, and kindness. These behaviours gain salience especially when compared to those of the Crusaders when they defeated the Muslims and occupied Islamicjerusalem in 1099 CE. Finally, it is clear that the holiness of Islamicjerusalem and its al-Aqsa Mosque had played a significant role in Salah al-Din's attitude and behaviours. Salah al-Din wanted the history to record these moments of rationality and tolerance, even with the enemies, to stress the role of Islamicjerusalem in spreading peace and safety

\section{REFERENCES}

Abu al-Fida', Isma'il Ibn ‘Ali (1997) Tarikh Abi al-Fida' al-Musamma al-Mukhtasar fi Akhbar alBashar. Beirut: Manshurat Muhammad 'Ali Baydun, Dar al-Kutub al-'Ilmiyyah.

Abu Shama, 'Abd al-Rahman Ibn Isma'íl (1997) Kitab al-Rawdatayn fi Akhbar al-Dawlatayn al-Nuriyya wal al-Salahiyya. Beirut: Mu'assasat al-Risalah.

Al-'Arif, 'Arif (1986) al-Mufassal fi Tarikh al-Quds. Jerusalem: Matba'it Al-Ma'arif. Al-Dhahabi, Shams al-Din Abi ‘Abd Allah (1999) Duwal al-Islam. Beirut: Dar Sader. 
Al-Hanbali, Mujir al-Din (1999) al-Uns al-Jalil bi Tarikh al-Quds wa al-Khalil. Hebron-Palestine: Maktabat Dandis.

Al-Hayik, Munther (2011) Al-'Asr Al-Ayyubi: Qarn Min al-Sira'at al-Dakhiliyya. Damascus: Dar Saafahat Lil Dirasat wa al-Nashr.

Al-Maqrizi, Abu al-'Abbas Ahmad Ibn 'Ali (1997) al-Suluk Li Ma'rifat Diwal al-Muluk. Beirut: Manshurat Muhammad 'Ali Baydun, Dar al-Kutub al-'Ilmiyyah.

Arnold, T. W (1986) The Preaching of Islam: A History of the Propagation of the Muslim Faith. London: Constable \& Co.

Dajani-Shikail, Hadia (1993) Al-Qadi al-Fadil 'Abd al-Rahman al-Bisani al-'Asqalani, (526596 AH /1131-1199 (E) Dawruhu al-Takhtiti fi Dawlet Salah al-Din wa Futuhateh. Beirut: Mu'assasat al-Dirasat al-Filastiniyyah.

Glubb, Faris (1999) 'Jerusalem: the central point in Saladin's life', Journal of Islamicjerusalem Studies, 2(2): 49-69.

Hillenbrand, Carol (2012) The Crusades: Islamic Perspective. Edinburgh: Edinburgh University Press.

Ibn al-'Adim, Kamal al-Din Abi al-Qasim (1996) Zubdat al-Halab min Tarikh Halab. Beirut: Dar al-Kutub al-'Ilmiyya.

Ibn al-'Ibri, Grigurius al-Malti (1992) Tarikh Mukhtasar al-Duwal. Beirut: Dar al-Mashreq.

Ibn al-Athir, Abu al-Hasan 'Ali al-Shaibani (1998) al-Kamil fi al-Tarikh. Beirut: Manshurat Muhammad 'Ali Baydun, Dar al-Kutub al-'Ilmiyya.

Ibn Shaddad, Baha’ al-Din (2000) al-Nawadir al-Sultaniyya wa'al-Mahasin al-Yusufiyya. Cairo: Dar al-Mana

Lane-Poole, Stanley (1985) Saladin and the fall of the Kingdom of Jerusalem. London: Darf Publishers.

'Ashur, Sa'id 'Abd al-Fattah (1968) 'Ba'd Adwa' Jadida 'la al-'laqat Bayn Misr wa alHabasha fi al-'Usur al-Wsta', al-Majala al-Misriyya al-Tarikhiyya. Vol. 14, p.1-43.

'Ashur, Sa'id 'Abd al-Fattah. (1986) al-Haraka al-Salibiyya, Safha Musharifa fi Tarikh al-Jihad al-Islami fi al-'Usur al-Wsta. Cairo: Maktabt al-Anjlu al-Masriyyah.

'Imad al-Din al-Asfahani, Abu 'Abd Allah Muhammad (n.d.). Kitab al-Fath al-Qussi fi al-Fath al-Qudsi. n.p.

Lyons, M. and Jackson, D (1982) Saladin, the Politics of the Holy War. Cambridge, UK: Cambridge University Press.

Amin Maalouf (2006), The Crusaders through Arab Eyes, trans. from the French by Jon Rothschild, London: Saqi Book, p. 50.

Meinardus, Otto (2002) The Thousand Years of Coptic Christianity. Cairo - New York: The American University in Cairo.

Morgan, M. R. (1973) The Chronicle of Ernoul and the Continuations of William of Tyre. London: Oxford University Press.

Regan, Geoffrey (1987) Saladin and the Fall of Jerusalem. London: Croom Helm.

Reston, James. Jr (2001) Warriors of God: Richard the Lionheart and Saladin in the Third Crusade. New York: Anchor Books.

Richards, D. S (2001) The Rare and Excellent History of Saladin or al-Nawadir al-Sultaniyya wa'l Mahasin al-Yusufiyya. English trans. of Ibn Shaddad, Al-Nawadir al-Sultaniyya wa'l Mahasin al-Yusufiyya. Hampshire: Ashgate.

Runciman, Steven. (1952) A History of the Crusades: The Kingdom of Jerusalem and the Frankish East (1100 - 1187). Cambridge, UK: Cambridge University Press.

Sawirus Ibn al-Muqaffa'(1959) Tarikh Batarikat al-Kanisah al-Misriyya, al-Ma'ruf bi Siyar alBai'a al-Muqaddasa, ed. 'Abd al-Masih, Y. and Suriyal, 'A, Cairo: n. p. 